\title{
Status of post harvest diseases of mango in Nothern Karnataka
}

\author{
Savita Chakrasali*, V. I. Benagi and Kotramma C. Addangadi \\ Department of Plant Pathology, College of Agriculture, University of Agricultural Sciences, DHARWAD \\ (KARNATAKA) INDIA (Email : savitachakrasali@gmail.com)
}

\begin{abstract}
Mango fruit suffers from many post harvest diseases among them anthracnose [Colletotrichum gloeosporioides (Penz) Penz and Sacc.] In stem end rot [Botryodiplodia theobromae (Pat.) Griffon and Maubl.], Alternaria rot (Alternaria alternata Keissal) and black mould (Aspergillus niger V. Tieghem) are the important diseases which contribute to the post harvest losses of mango. The market survey conducted during 2015 in Dharwad, Gadag and Uttara Kannada districts revealed that, among the post harvest diseases of mango anthracnose showed maximum PDI (14.25) followed by stem end rot (8.85) and Alternaria rot showed least PDI (5.10). Among the districts surveyed maximum PDI (10.98) was recorded in Dharwad followed by Hubballi (9.01) and least PDI (6.53) was recorded in Ankola. Among varieties, Alphanso showed maximum PDI (10.66) followed by Pairi (7.83) and least PDI was observed in Ishadi (6.40) and Neelam (6.22). The PDI ranged from 6.22 to 10.66.
\end{abstract}

Key Words : Post harvest diseases, Mango, Market survey

View Point Article : Chakrasali, Savita, Benagi, V. I. and Addangadi, Kotramma C. (2018). Status of post harvest diseases of mango in Nothern Karnataka. Internat. J. agric. Sci., 14 (1) : 207-210, DOI:10.15740/HAS/IJAS/14.1/207-210.

Article History : Received : 02.06.2017; Revised : 03.12.2017; Accepted : 15.12.2017

\footnotetext{
* Author for correspondence:
} 